\title{
АНАЛІЗ РОЗВИТКУ ВАЖКИХ БПАК В УКРАЇНІ НА ПРИКЛАДІ ПРОЕКТУ "ГОРЛИЦЯ"
}

\begin{abstract}
Державне підприємство “АНТОНОВ”
Проведено аналіз розвитку вітчизняних БпАК злітною вагою вище 150 кг. Подано оцінку зарубіжного прикладу розвитку БпАК. Виявлено лінію тренду розвитку зарубіжних БпАК Class II (150 kg - 600 kg), Class III (>600 kg) у період 2007-2021 pp. на прикладі Туреччини. Визначено прогнозований тренд розвитку БпАК в Україні, що ґрунтується на подальшому розвитку проекту “Горлиця" (ДП “АНТОНОВ”). Проект “Горлиця" стартував в Україні з "нульової відмітки", ніякого заділу для створення БпАК важких класів (250 кг, 3000 кг, 7500 кг) в Україні не було. Це абсолютно новий, складний та перспективний напрям розвитку ОВТ. Це повністю вітчизняна кооперація співвиконавців проекту за усіма складовими БпАК. Проект “Горлиця" реалізується в Системі розроблення і поставлення на виробництво озброєння та військової техніки СРПВ ОВТ, яка включає в себе структуру Державного замовника (у Міноборони це Департамент ВТП, розвитку ОВТ МО України); інститут Державного замовника (у Міноборони це ЦНДІ ОВТ ЗСУ); військові представництва Державного замовника на підприємствах; підприємства оборонної промисловості. У 2016 році на полігонах 3С України проходили етап визначальних відомчих випробувань більше ніж 20 вітчизняних БпАК, триває підконтрольна експлуатація цих БпАК у військах, решта з них вже завершила цю експлуатацію, пройшла процедуру прийняття на озброєння, є прийнятими на озброєння, серійно виготовляються та постачаються у війська.

Нормативним базисом для виконання проекту $є$ документ про порядок розроблення, освоєння та випуску нових видів продукції оборонного призначення, а також припинення випуску видів такої продукції.

Запропоновано варіант дорожньої карти розвитку важких БпАК в Україні на період до 2030 року.

Ключові слова: безпілотний авіаційний комплекс, класифікація БпАК, злітна вага, дослідно-конструкторська робота, наземна станція керування, завадозахищена радіолінія, стандарти HATO STANAG, тренд розвитку, дорожня карта.
\end{abstract}

\section{Метою статті є:}

по-перше, дати тлумачення, що розуміється під словом "розвиток" взагалі та під словосполученням "розвиток важких БпАК в Україні” зокрема, показати стан розвитку важких БпАК у загальній картині розвитку БпАК в Україні;

по-друге, висвітлити історію появи, стан і проблеми реалізації проекту “Горлиця";

по-третє, навести зарубіжний приклад розвитку БпАК та запропонувати на підставі аналізу цього прикладу варіант дорожньої карти для розвитку важких БпАК в України.

Що таке “розвиток”? Словник дає таке загальне тлумачення цього слова: "розвиток - це процес, в результаті якого відбувається змінення якості чого-небудь, перехід від одного якісного стану до іншого, вищого”.

Що таке “розвиток важких БпАК в Україні”? У цій публікації робиться спроба відповісти на це запитання.

Стан розвитку БпАК в Україні. Стан розвитку вітчизняних важких БпАК (Class II (150 kg - $600 \mathrm{~kg})$, Class III (>600 kg)) у загальній картині розвитку БпАК в Україні наведено на рис. 1. 


\begin{tabular}{|c|c|c|c|c|c|c|c|}
\hline \multicolumn{7}{|c|}{ NATO UAS CLASSIFICATION } & \multirow[b]{2}{*}{$\begin{array}{c}\text { Наявність } \\
\text { вітчизняного } \\
\text { БпАК }\end{array}$} \\
\hline Class & Category & $\begin{array}{c}\text { Normal } \\
\text { Employment }\end{array}$ & $\begin{array}{l}\text { Normal } \\
\text { Operating } \\
\text { Altitude }\end{array}$ & $\begin{array}{c}\text { Normal } \\
\text { Mission } \\
\text { Radius }\end{array}$ & $\begin{array}{c}\text { Primary } \\
\text { Supported } \\
\text { Commander }\end{array}$ & $\begin{array}{l}\text { Example } \\
\text { Platform }\end{array}$ & \\
\hline \multirow{3}{*}{$\begin{array}{l}\text { Class III } \\
(>600 \mathrm{~kg})\end{array}$} & $\begin{array}{c}\text { Strikel } \\
\text { Combat }^{*}\end{array}$ & Strategic/National & Up to $65,000 \mathrm{ft}$ & $\begin{array}{c}\text { Unlimited } \\
\text { (BLOS) }\end{array}$ & Theatre & Reaper & \\
\hline & HALE & Strategic/National & Up to $65,000 \mathrm{ft}$ & $\begin{array}{c}\text { Unlimited } \\
\text { (BLOS) }\end{array}$ & Theatre & Global Hawk & \\
\hline & MALE & Operational/Theatre & $\begin{array}{l}\text { Up to } 45,000 \mathrm{ft} \\
\mathrm{MSL}\end{array}$ & $\begin{array}{c}\text { Unlimited } \\
\text { (BLOS) }\end{array}$ & JTF & Heron & \\
\hline $\begin{array}{l}\text { Class II } \\
(150 \mathrm{~kg} \text { - } \\
600 \mathrm{~kg})\end{array}$ & Tactical & Tactical Formation & $\begin{array}{c}\text { Up to } 18,000 \mathrm{ft} \\
\text { AGL }\end{array}$ & $\begin{array}{l}200 \mathrm{~km} \\
\text { (LOS) }\end{array}$ & Brigade & Hermes 450 & \\
\hline \multirow{3}{*}{$\begin{array}{l}\text { Class I } \\
(<150 \mathrm{~kg})\end{array}$} & $\underset{(>15 \mathrm{~kg})}{\text { Small }}$ & Tactical Unit & $\begin{array}{l}\text { Up to } 5,000 \mathrm{ft} \\
A G L\end{array}$ & $\begin{array}{l}50 \mathrm{~km} \\
\text { (LOS) }\end{array}$ & $\begin{array}{l}\text { Battalion, } \\
\text { Regiment }\end{array}$ & Scan Eagle & \\
\hline & $\underset{(<15 \mathrm{~kg})}{\operatorname{Mini}}$ & $\begin{array}{l}\text { Tactical Subunit } \\
\text { (manual or hand } \\
\text { launch) }\end{array}$ & $\begin{array}{c}\text { Up to } 3,000 \mathrm{ft} \\
\text { AGL }\end{array}$ & $\begin{array}{c}\text { Up to } 25 \\
\mathrm{~km} \text { (LOS) }\end{array}$ & $\begin{array}{l}\text { Company, } \\
\text { Platoon, } \\
\text { Squad }\end{array}$ & Skylark & \\
\hline & $\begin{array}{r}\text { Micro ** } \\
(<66 \mathrm{~J})\end{array}$ & $\begin{array}{l}\text { Tactical Subunit } \\
\text { (manual or hand } \\
\text { launch) }\end{array}$ & $\begin{array}{l}\text { Up to } 200 \mathrm{ft} \\
A G L\end{array}$ & $\begin{array}{l}\text { Up to } 5 \mathrm{~km} \\
\text { (LOS) }\end{array}$ & $\begin{array}{l}\text { Platoon, } \\
\text { Squad }\end{array}$ & Black Widow & \\
\hline
\end{tabular}

Рис. 1. Стан розвитку вітчизняних БпАК відповідно до класифікації NATO - наявність вітчизняного БпАК у складі ЗС України - відсутність вітчизняного БпАК у складі ЗС України

Якщо брати оцінку стану розвитку вітчизняних БпАК Class I (<150kg), то вона характеризується такими показниками: у 2016 році на полігонах 3С України проходили етап визначальних відомчих випробувань більше ніж 20 вітчизняних БпАК, триває підконтрольна експлуатація цих БпАК у військах, решта з них вже завершила цю експлуатацію, пройшла процедуру прийняття на озброєння, прийняті на озброєння, серійно виготовляються та постачаються у війська. Загальна кількість БпАК Class I $(<150 \mathrm{~kg})$, які експлуатуються у військах нараховується вже не десятками, а сотнями одиниць БпЛА, вітчизняні компаніївиробники готуються до постачання або вже постачають ці комплекси на експорт, триває постійне удосконалення, модернізація та покращання ТTX вітчизняних БпАК цього класу, створена система ремонту, обслуговування та навчання. Все це $\epsilon$ безперечно розвитком, і ми бачимо на рисунку показники, які свідчать про це. Показники для Class II (150 kg - $600 \mathrm{~kg})$ та Class III (>600 kg) вочевидь демонструють стан розвитку вітчизняних БпАК цих класів. У статті зроблено спробу розібратися у цьому питанні та відповісти на запитання "що робити?”, а також запропонувати один з можливих варіантів дорожньої карти для виходу з цієї ситуації.

Історія появи проекту “Горлиця”. Як свідчить попередній досвід розроблення ОВТ в Україні, військові проекти зазвичай проходили шлях від звернення підприємства на МО України з ініціативою щодо розроблення (модернізації) зразка ОВТ через відкриття ДКР. При цьому науково-технічний заділ для цих проектів на підприємстві вже існував. У випадку проекту "Горлиця" цей проект стартував в Україні з “нульової відмітки", ніякого заділу для 
створення БпАК важких класів (250 кг, 3000 кг, 7500 кг) в Україні не було, це абсолютно новий, складний та перспективний напрям розвитку ОВТ, тому шлях проекту був навпаки від МО України до ДП “АНТОНОВ". Цей шлях був розпочатий у квітні 2014 року. ЦНДІ ОВТ ЗСУ, як Головна НДУ МО України 3 воєнно-технічних питань, на підставі аналізу тенденції розвитку збройної боротьби, стрімкого розвитку БпАК в світі, а також з урахованням високої ефективності їх застосування у збройних конфрліктах в Іраку, Афрганістані та Грузії приділяє цьому перспективному напрямку особливу увагу та проводить НДР щодо дослідження можливості промислової реалізації в Україні БпАК різних класів (від мікро- до стратегічних). У межах цього дослідження картки експертного опитування надсилаються до 18 підприємств (установ) України близьких за профрілем діяльності до нової тематики щодо розроблення БпАК. На підставі аналізу та обробки карток, які офріційно за підписами керівників надійшли до інституту, були відпрацьовані ранговані переліки можливих потенційних виконавців ДКР за класами БпАК. При цьому ДП "АНТОНОВ" очолює перелік підприємств, які мають перспективу промислової реалізації в Україні складних проектів створення саме важких БпАК від тактичного до оперативно-тактичного, оперативного та стратегічного класів.

Таким чином, саме в межах виконання НДР у МО України ДП “АНТОНОВ", як провідне підприємство авіаційної галузі України, було залучено до робіт за напрямком розвитку важких БпАК військового призначення.

Стан реалізації проекту “Горлиця". Проект "Горлиця" - це приклад “класичної ДКР”. Термін “класична ДКР” у цьому контексті означає проведення послідовних етапів: від досліджень НДУ Замовника (ЦНДІ ОВТ ЗСУ) у межах НДР 3 аналізу тенденцій змін збройної боротьби у світі до обґрунтування перспективного напрямку розвитку нової зброї для ЗС України, фоомування ОТВ та ТTВ, погодження зі споживачем - видом 3С України та затвердження у МО України Рішення про відкриття ДКР, формування ТТЗ та надання його Головному виконавцю, укладання Договору між Головним виконавцем та Державним замовником, виконання етапів ДКР та прийняття їх комісіями МО України, проведення Державних випробувань 3 перевірки відповідності дослідного зразка вимогам ТТЗ, прийняття зразка на озброєння, серійне виробництво промисловістю та постачання зразків у війська, експлуатація у військах, підтримка експлуатації та модернізація зразка впродовж життєвого циклу. Все це частково вже реалізовано та було с самого початку передбачено у проекті “Горлиця”.

Проект "Горлиця" реалізується в Системі розроблення і поставлення на виробництво озброєння та військової техніки СРПВ ОВТ, яка включає структуру Державного замовника (у Міноборони це Департамент ВТП, розвитку ОВТ МО України); інститут Державного замовника (у Міноборони це ЦНДІ ОВТ ЗСУ); військові представництва Державного замовника на підприємствах; підприємства оборонної промисловості.

Нормативним базисом для виконання проекту $є$ документ про порядок розроблення, освоєння та випуску нових видів продукції оборонного призначення, а також припинення випуску видів такої продукції [2].

У проекті “Горлиця" були реалізовані такі етапи:

2014 рік - проведена НДР з дослідження можливостей промислової реалізації БпАК в Україні, підготовлено проект Рішення про відкриття ДКР;

2016 рік - затверджено Рішення про відкриття ДКР; 


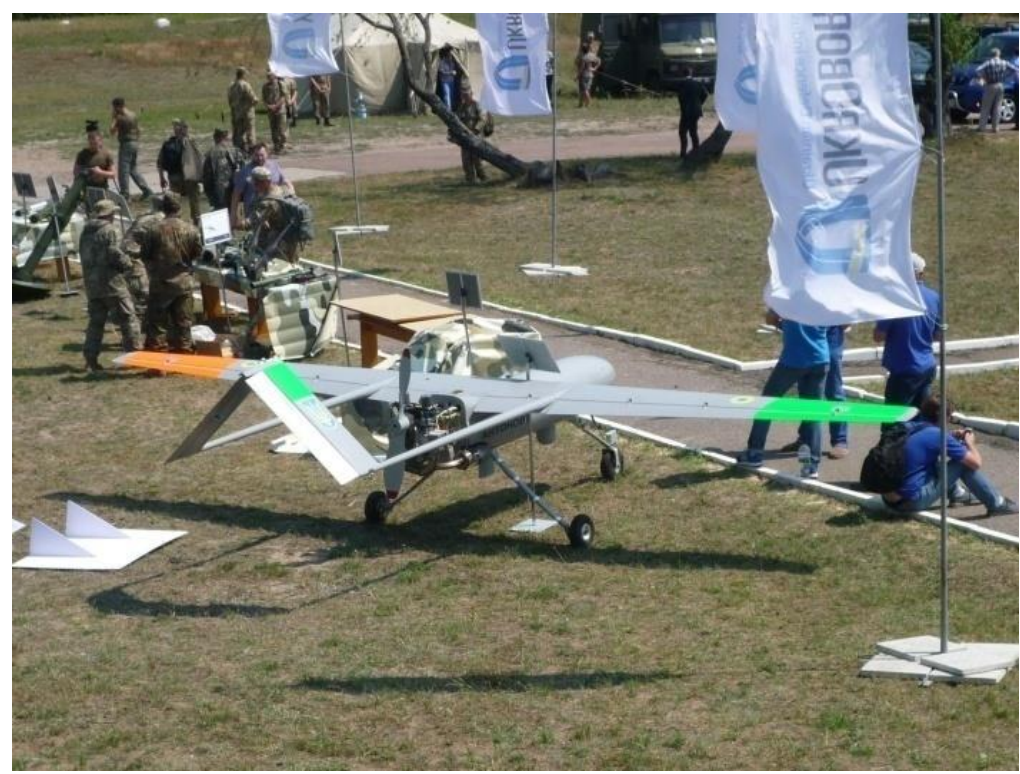

Рис 2. Презентація проекту “Горлиця” для 3С України (травень 2017 р.)

2016 рік - затверджено та подано ТТЗ до ДП “АНТОНОВ”;

2016 рік - виконано та захищено з позитивним Висновком від комісії МО України етап ДКР “Розроблення технічного проекту”;

2017 році - презентація проекту для представників 3С України та МО України на військовому полігоні у Чернігівській області;

2017 рік - демонстраційний показ польоту БпЛА АН-БК-1 для представників РНБОУ, МОУ, НГ, ЗСУ, ТВ каналів та журналістів;

2018-2019 роки - робоче проектування за темою “Горлиця-2";

2020 рік - виробництво прес-форм для виготовлення композитного інтегрованого фрюзеляжу, збільшення злітної ваги БпЛА з 150 до 250 кг з метою забезпечення можливості переходу до реалізації ударного варіанту проекту “Горлиця-2".

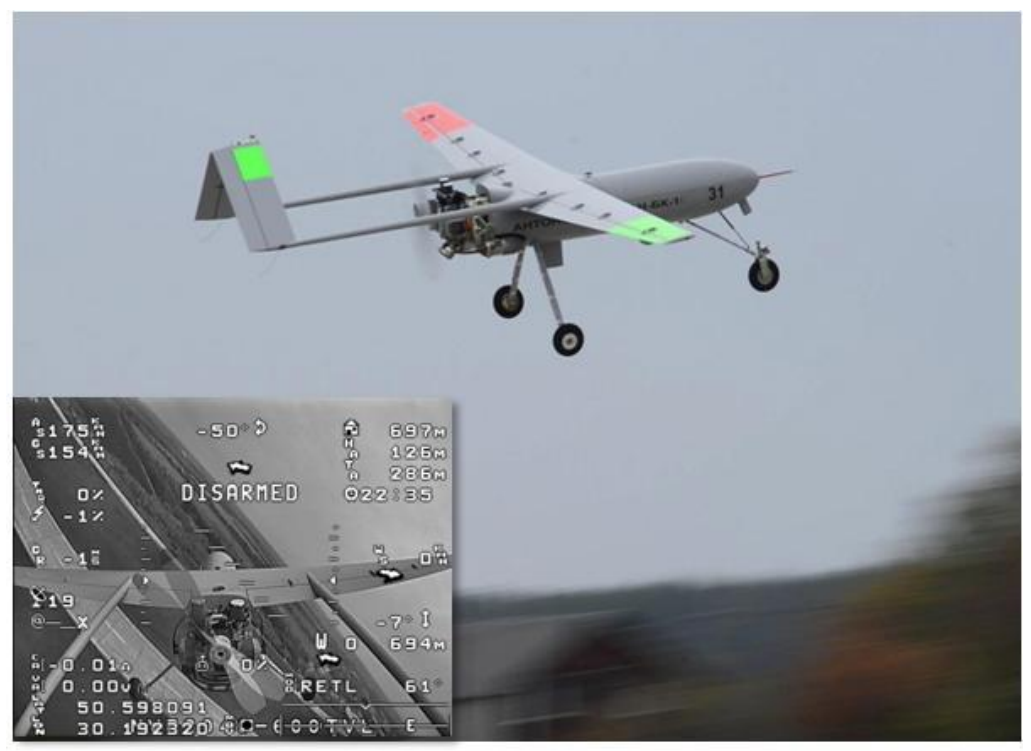

Рис 3. Демонстраційний показ польоту АН-БК-1 для РНБОУ, МОУ, НГ, ЗСУ, ТВ каналів (вересень 2017 р.) 


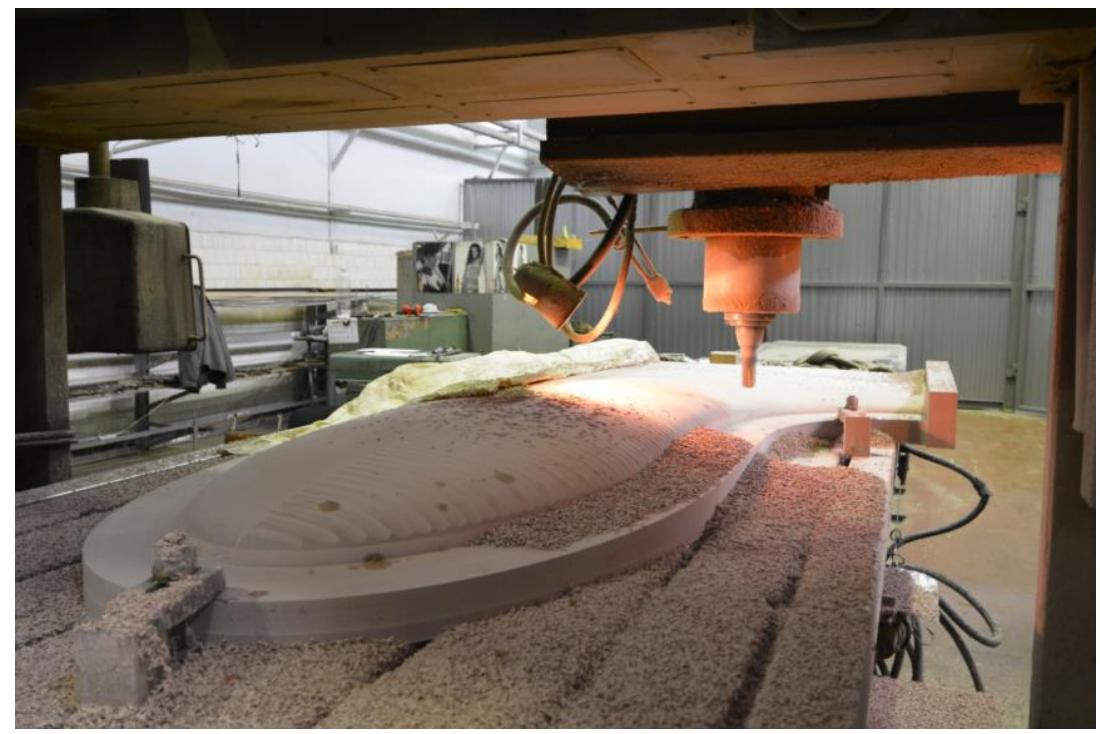

Рис 4. Обробка форми для оснастки, що застосовується при виготовленні інтегрованого композитного фюзеляжу для проекту “Горлиця-2” (січень 2020 р.)

\section{ДП “АНТОНОВ” на сьогодні проводить роботи:}

у межах проекту “Горлиця-1" - розроблення програмних засобів і робочих місць щодо моделювання та налаштування автопілота, відпрацювання методики проведення попередніх льотних випробувань;

у межах проекту “Горлиця-2" - виготовлення складових частин БпАК, виготовлення оснастки - прес-фрорм для композитних елементів конструкції планера.

Роботи співвиконавців за складовими частинами БпАК у межах проекту “Горлиця" призупинено у зв'язку з відсутністю державного фрінансування.

Унікальні властивості проекту “Горлиця". Це повністю вітчизняна кооперація співвиконавців проекту за усіма складовими БпАК. Кооперація вперше була представлена на захисті Технічного проекту перед комісією МО України, при цьому кожен співвиконавець захищав свої книги (розділи) Технічного проекту. Основні співвиконавці: ДП "Івченко-Прогрес" (м. Запоріжжя) - силова установка; Науково-дослідний інститут радіотехнічних вимірювань (м. Харків) - обладнання командно-телеметричної радіолінії та радіолінії передачі даних; ТОВ “Телекарт Прилад" (м. Одеса) - наземна станція керування, наземний тактичний зв'язок, віддалений відеотермінал, інтеграція 3 АСУ ЗСУ; ДП “АНТОНОВ” - НВП “Хартрон-Аркос” ЛТД (м. Харків) - центральний обчислювач з функцією автопілота; ДП "Ізюмський приладобудівний завод" (м. Ізюм) - оптико-електронна система повітряної розвідки. У межах проекту "Горлиця-2" до цієї кооперації долучається ДП ДККБ “Луч” (м. Київ) розроблення високоточних боєприпасів для БпЛА.

Зменшення вартості та зниження технічних ризиків у проекті “Горлиця" $€$ можливим завдяки використанню уніфікованих складових частин, які пройшли випробування на інших зразках озброєння, це у першу чергу стосується автоматизованих робочих місць (АРМ) операторів БпЛА, які використовуються у НСК БпАК.

Усі підприємства, які складають кооперацію проекту “Горлиця”, мають успішно завершені розробки для МО України, а саме прийняті на озброєння 
зразки ОВТ, серійно їх виготовляють для потреб МО України і постачають у війська, виробництво відповідає військовим стандартам і контролюється військовими представництвами замовника.

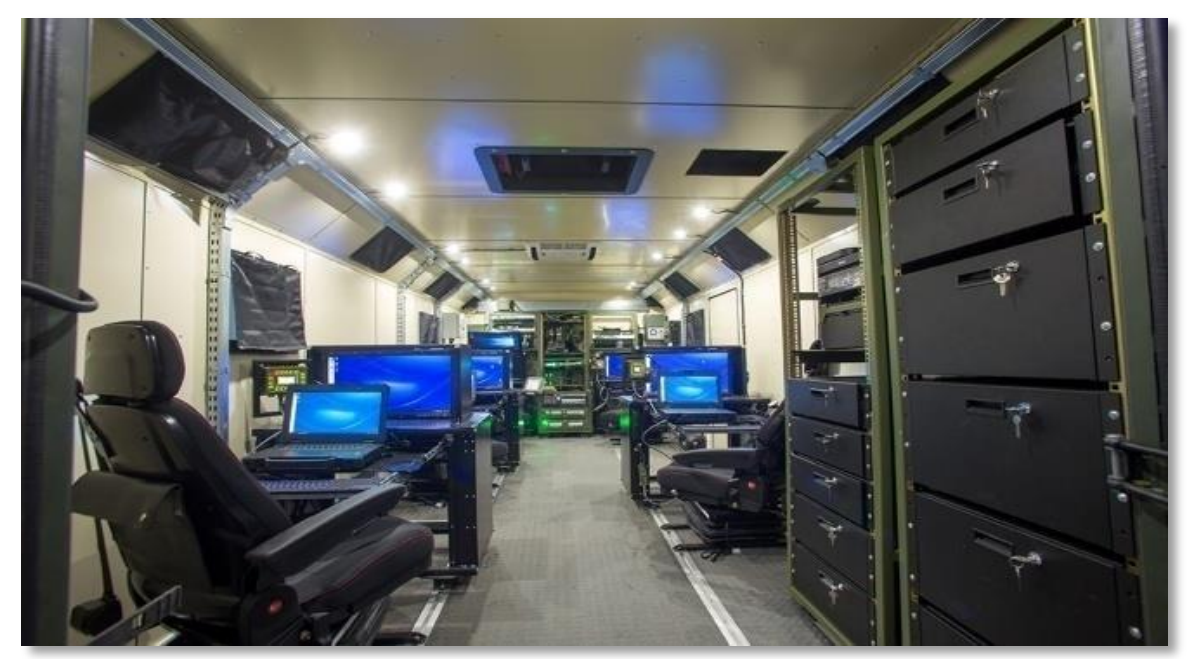

Рис 5. Уніфікована наземна станція керування (НСК) БпАК, ТОВ “Телекарт Прилад” (м. Одеса)

Врахування досвіду застосування БпЛА в АТО (ООС). Досвід застосування операторами БпЛА, що був набутий у зоні проведення АТО (ООС), в умовах активної протидії з боку засобів РЕБ та ППО був практично втіленим у вимоги ТТЗ, що було надано військовими до ДП “АНТОНОВ".
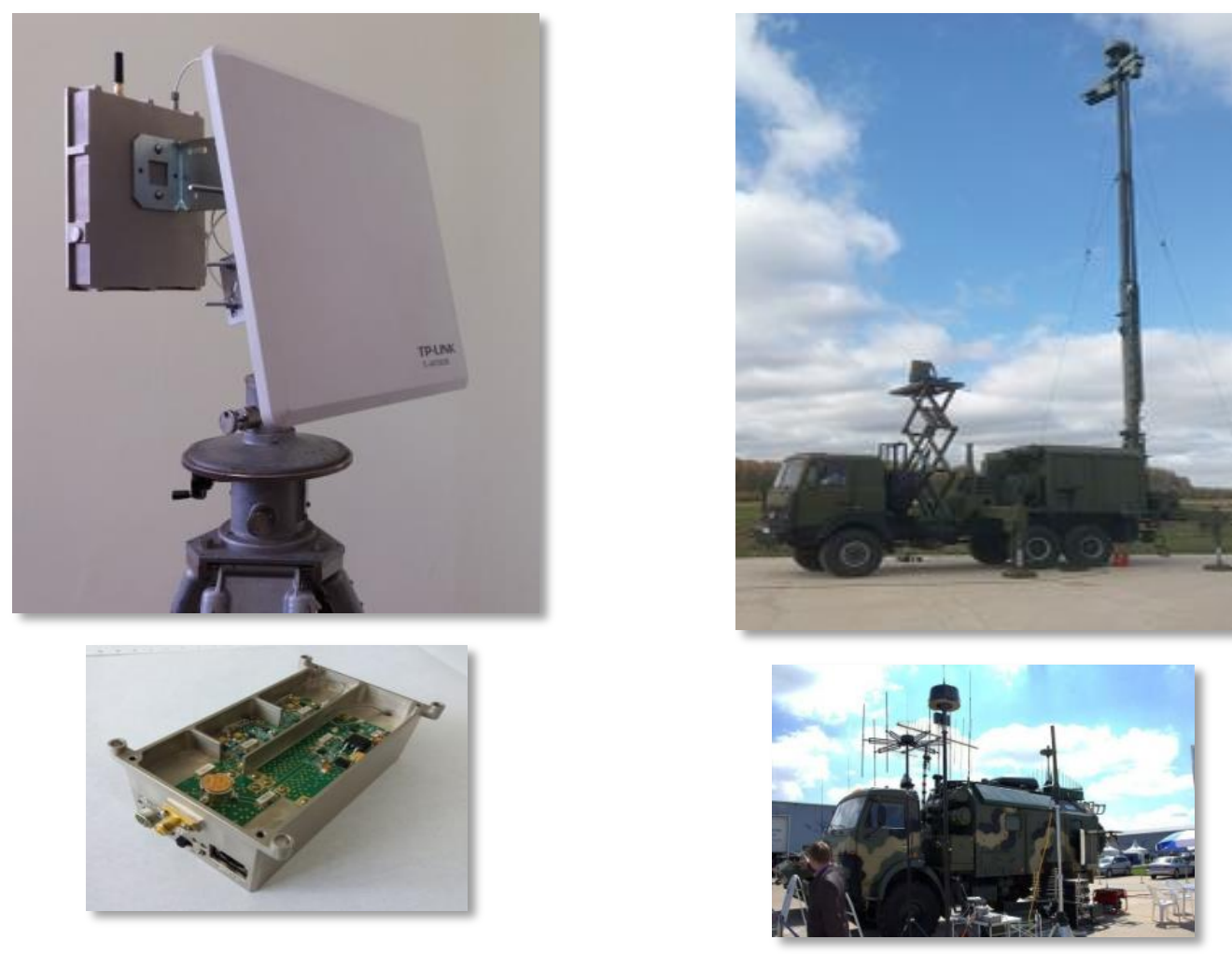

Рис 6. Розробка завадозахищеної від засобів РЕБ радіолінії БпЛА 
На сьогодні можна стверджувати, що жодний зарубіжний зразок аналогічного класу БпЛА проекту “Горлиця" не відповідає цим вимогам вимогам ЗСУ, оскільки зарубіжні зразки створювалися в інший період часу, для інших умов бойового застосування, для іншого противника, для своїх, у першу чергу національних збройних сил з урахуванням їх тактики та досвіду бойового застосування у військових конфліктах.

Відповідність проекту “Горлиця" вимогам STANAG, забезпечення сумісності 3 системами керування та озброєння країн-членів НАТО. Вперше в розробленні авіаційного проекту військового призначення до ТТЗ включено 4 документи зі стандартизації НАТО. Представники ДП "АНТОНОВ” $€$ постійними учасниками робочої групи НАТО зі стандартизації в галузі безпілотних авіаційних систем - "Unmanned Aerial System (UAS)". У межах роботи цієї групи вони беруть активну участь у засіданнях робочої групи, обговоренні проектів стандартів, виступають з презентаціями власного досвіду, зокрема врегулювання польотів БпЛА у повітряному просторі України, процедури отримання дозволу на польоти дослідних зразків важких БпЛА, організації та проведення їх випробувань в Україні.

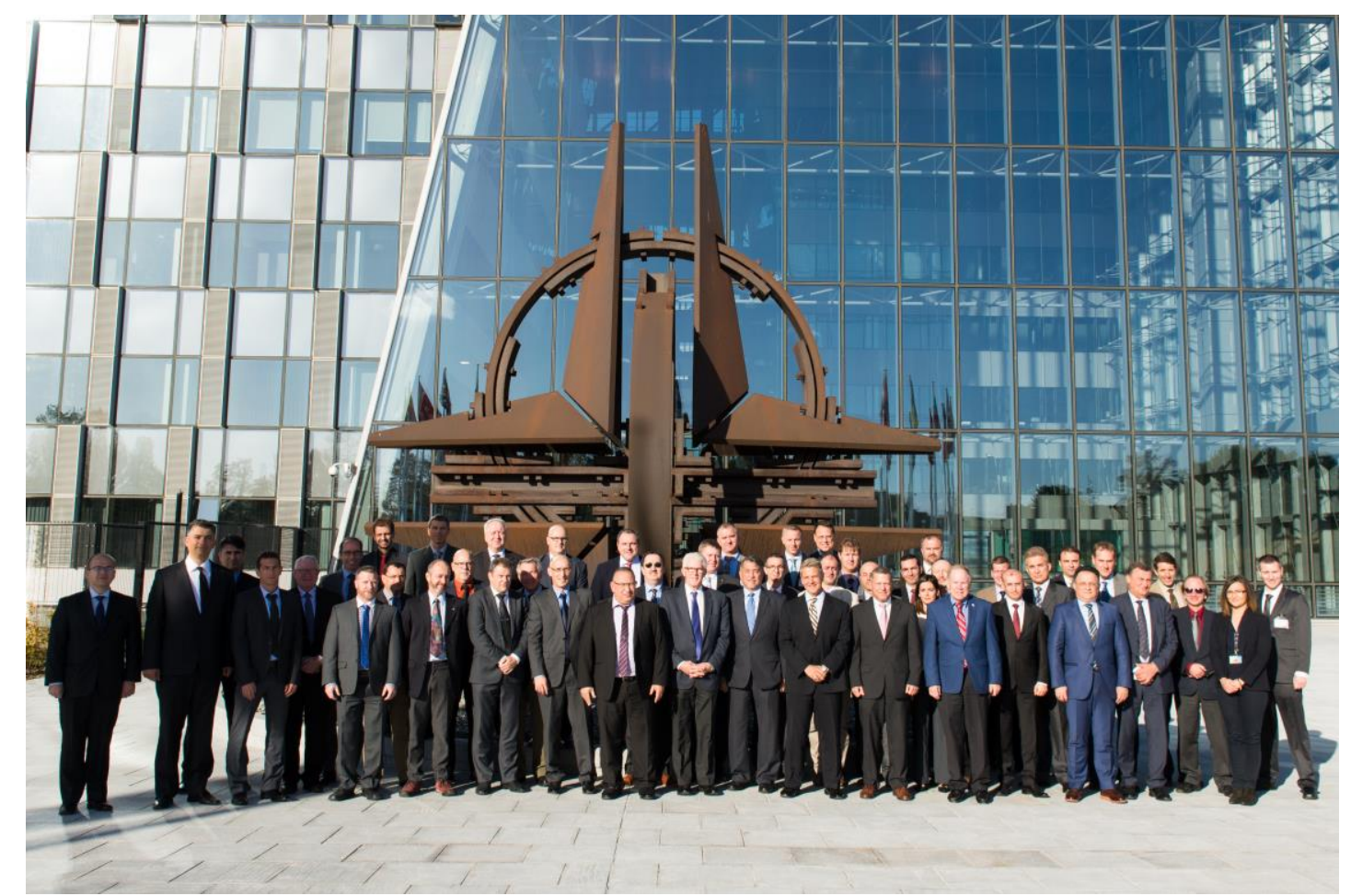

Рис 7. Участь представників ДП “АНТОНОВ” у роботі групи НАТО з розробки стандартів STANAG за напрямом “Unmanned Aerial System (UAS)”

Однак головним досягненням участі у цій роботі $€$ відпрацювання механізму отримання документів НАТО зі стандартизації для підприємств вітчизняної промисловості 3 урахуванням можливостей реалізації програми НАТО для країн-партнерів, в якій Україна бере активну участь.

До позитивних результатів слід віднести отримання офіційним шляхом останніх редакцій електронних версій документів зі стандартизації НАТО STANAG, які вже сьогодні використовують ДП "АНТОНОВ" та підприємства співвиконавці проекту у роботі, що продемонстровано на рис. 8. 
Проблеми реалізації проекту “Горлиця". Проект зупинився на позитивному Висновку комісії МО України від 28 липня 2016 року, яка визначала, що Технічний проект ДКР 3 шифром “Горлиця" вважається виконаним та прийнятим із зауваженнями та рекомендаціями, а також вважала за доцільне перейти до виконання наступного етапу ДКР з шифром “Горлиця". Висновок був поданий до Департаменту МО України, який займається розвитком ОВТ, на затвердження, але договір на виконання ДКР не був укладений.

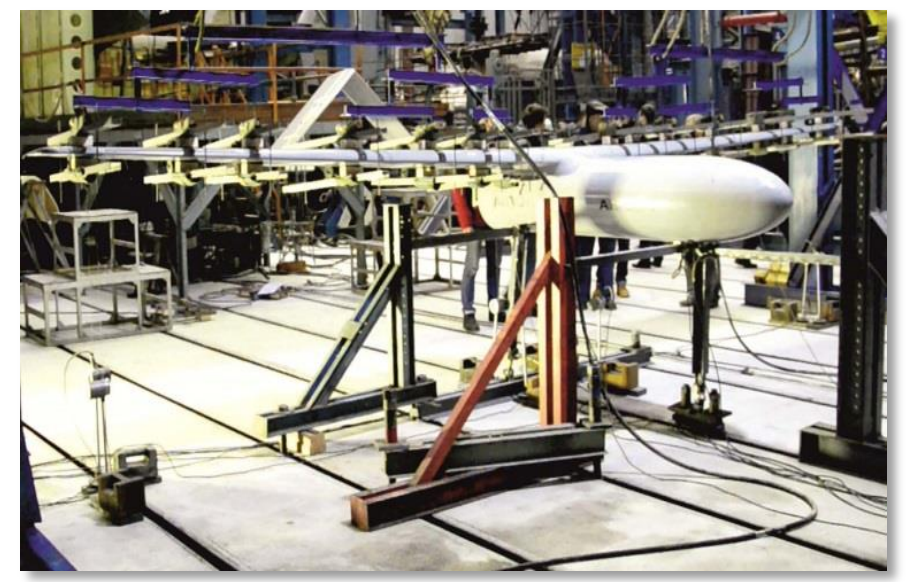

Рис 8. Перевірка на міцність крила відповідно до вимог STANAG 4671 у залі статичних випробувань ДП "АНТОНОВ"

Зарубіжний приклад розвитку БпАК. Повідомлення від 12 січня 2019 р. IНТЕРФАКС-Україна: "Державна компанія "Укрспецекспорт" і турецька компанія Baykar Makina підписали угоду про закупівлю для української армії ударних безпілотників Bayraktar TB" [3]. Цей шлях до успіху укладеної Угоди про закупівлю БпАК наведено на рис. 9.

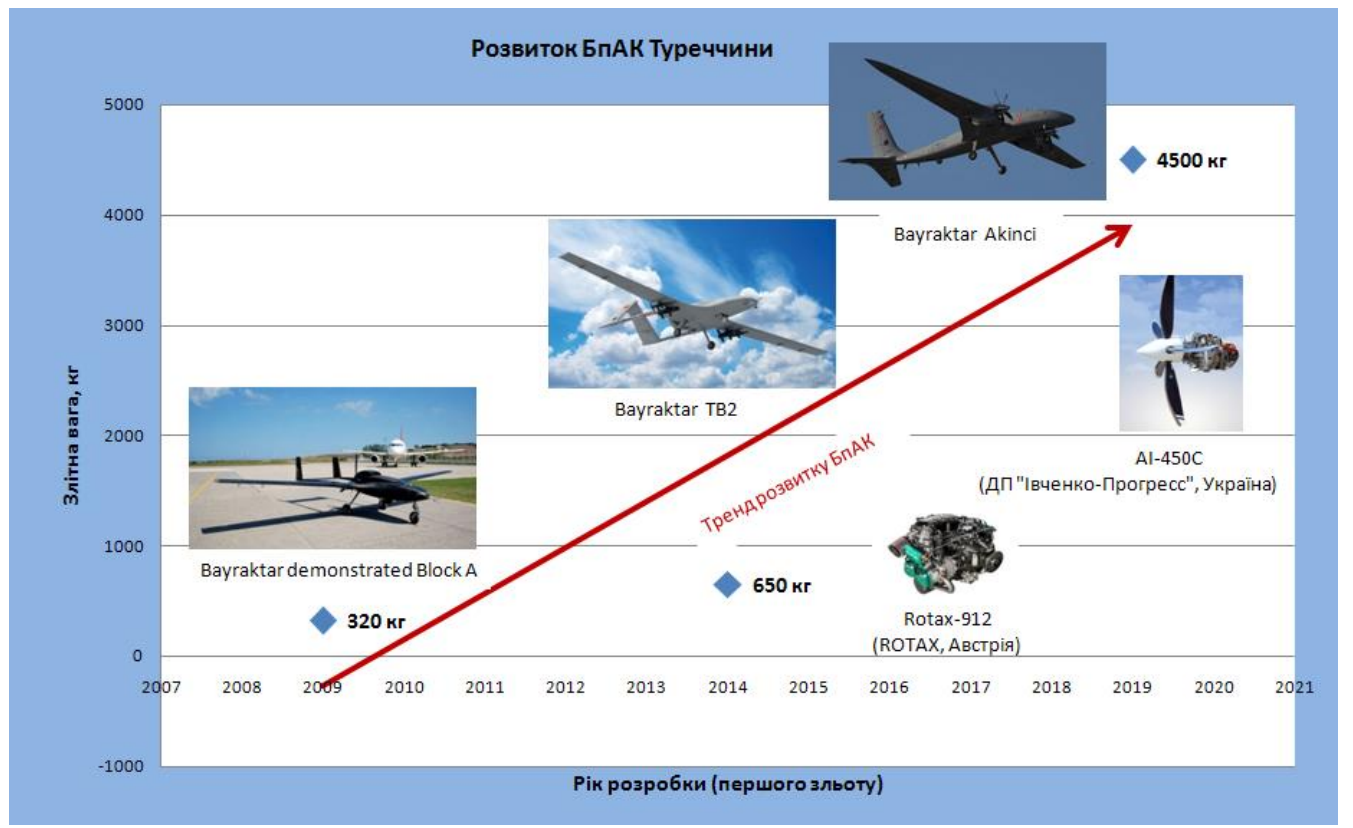

Рис. 9. Розвиток БпАК Туреччини у період 2009 - 2021 рр. 
БпЛА чорного кольору має назву "Bayraktar demonstrated BlockA", це саме той демонстратор, з яким компанія Baykar Makina у 2009 році перемогла у тендері для збройних сил Туреччини. Але зараз у серійному виробництві це зовсім інший БпАК, оскільки в цьому і $\epsilon$ розвиток: від демонстратора до серійного БпАК - це шлях, на якому зразок покращується, змінюється, лікуються його "дитячі хвороби росту" і змінюються не лише ТTХ, а й зовнішній вигляд. Таким чином, шлях до успіху складався з таких кроків: потреба власних збройних сил (державне замовлення), тендер (конкурс), контракт, що передбачає фрінансування від держави, серійне виробництво, постачання у війська, експлуатація та бойове застосування, постачання на експорт. Після досягнення результату у класі "Tactical UAV" перехід до нового етапу створення БпАК - більш високого класу "HALE", ось що таке розвиток на зарубіжному прикладі.

Лінія тренду на рис. 9 наглядно демонструє фрізичний смисл поняття "розвиток", це кут нахилу лінії тренду залежно від часу, а саме, року розроблення (першого зльоту) зразка та досягнутого технічного рівня зразка максимальної злітної ваги, яка включає в себе також і вагу озброєння. Таким чином, чим кут більше, тим стрімкіше відбувається розвиток. Цей приклад не $є$ унікальним, це загальносвітова практика і цей досвід потрібно враховувати Україні, іншого шляху розвитку немає.

Варіант дорожньої карти для розвитку важких БпаК в Україні. Дорожня карта, що пропонується, враховує зарубіжний досвід з цього питання, братися за більш “складні" проекти БпАК доцільно лише після досягнення результату на більш “простих", це дає можливість, по-перше, зменшити ризики саме для військових щодо можливого сценарію фрінансування проекту складного озброєння, яке ніколи не буде реалізовано та прийнято на озброєння ЗСУ, подруге, отримати необхідний рівень компетенції вітчизняними підприємствами, які задіяні у кооперації, цей напрям не є “бронетехніка", або “ПТРК", або "радіолокаційна техніка", тут не можливо відштовхнутися від досягнутого попереднього рівня озброєння, тому що для важких БпАК немає цього рівня. Це абсолютно новий проект для України, і він $є$ індикатором, іншими словами, тестом на спроможність вітчизняної промисловості, науки, освіти, технологій, виробництва, кадрів розробляти, освоювати та виготовляти нові сучасні, складні, конкурентоспроможні на світовому ринку високотехнологічні комплекси озброєння.

Основна ідея дорожньої карти - підтримати вітчизняний проект “Горлиця", а через цей проект підтримати вітчизняну кооперацію промисловості, забезпечити його стійке фрінансування, контроль виконання з боку військових представництв та комісій МО України, здійснювати його всебічне науковотехнічне супроводження та підтримку щодо процесів набуття компетенції та досвіду промисловістю.

За результатами успіху цього проекту та на його базі, а саме на базі досягнутого технічного рівня зразка, необхідно перейти на розробку у середньостроковій перспективі з 2025 року БпАК більш високого класу MALE та у достроковій перспективі з 2030 року БпАК класу HALE з силовими установками вітчизняного виробництва MS-500V та Al-450C.

Таким чином, настав час прийняти рішення щодо підтримки та розвитку цього напрямку в Україні, якщо втратити час, то може настати момент, коли буде знайдено фрінансовий ресурс на виконання ДКР, а люди, їх професійні 
навички та технології у вітчизняних авіабудуванні, двигунобудуванні, радіозв'язку, оптико-електронних системах та інших напрямках промисловості та науки можуть бути втрачені.

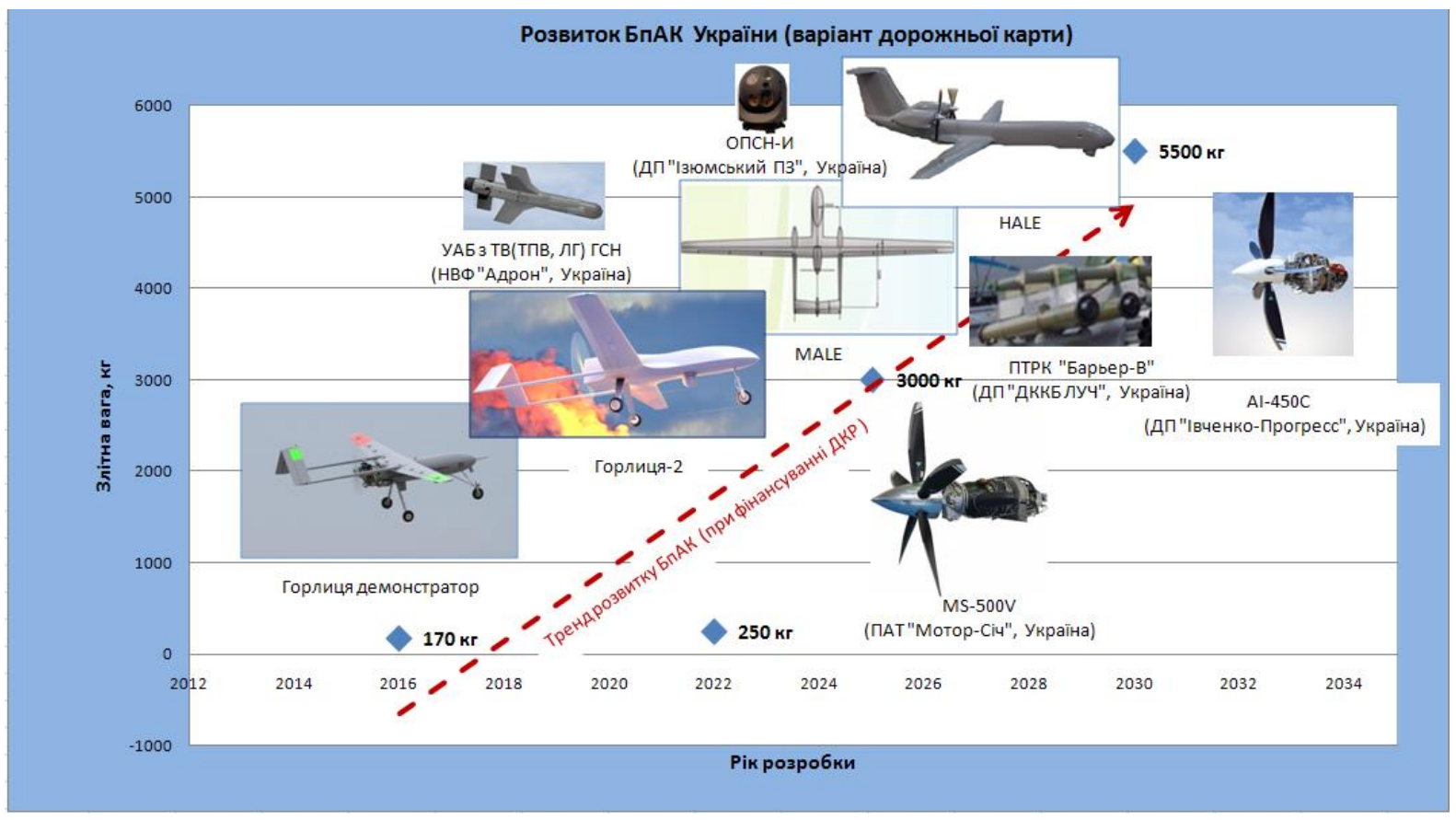

Рис. 10. Варіант дорожньої карти розвитку важких БпАК в Україні на період до 2030 року

Висновок. У статті запропоновано варіант дорожньої карти розвитку важких БпАК в Україні на період до 2030 року.

Дорожня карта пропонується для обговорення експертами, військовими, представниками промисловості, а також посадовими особами державних структур Офісу Президента України, Верховної Ради України, РНБО України, МО України для прийняття рішень щодо розвитку важких БпАК в Україні.

Резюме. На запитання, яке було поставлено на початку статті, можна дати дуже просту відповідь: “розвиток важких БпАК в Україні - це рух вперед". Це лінія тренду, яка $є$ не пунктирною, а суцільною червоною лінією, яка не є горизонтальною з нульовим кутом нахилу, а направлена у гору, у майбутнє української безпілотної авіації, а у підсумку - у майбутнє вітчизняної промисловості, освіти та науки.

\section{Список літератури}

1. NATO. STANAG 4670. GUIDANCE FOR THE TRAINING OF UNMANNED AIRCRAFT SYSTEMS (UAS) OPERATORS. NATO Standard. - May 8, 2019. - 6 p.

2. Порядок розроблення, освоєння та випуску нових видів продукції оборонного призначення, а також припинення випуску видів такої продукції. Постанова Кабінету Міністрів України. № 120. - 20.02.2013.

3. Електронний ресурс // interfax.com.ua

\section{References}


1. NATO. STANAG 4670. GUIDANCE FOR THE TRAINING OF UNMANNED AIRCRAFT SYSTEMS (UAS) OPERATORS. NATO Standard. - May 8, 2019. - 6 p.

2. Poryadok rozroblennya, osvoennya ta vypusku novyh vydiv productsii oboronnogo priznachennya, a takozh pripinennya vypusku vydiv takoi productsii. Postanova Cabinetu Ministriv Ukrainy vid 20.02.2013 No. 120 [Procedure for, development and release of new types of defense products, as well as termination of production of such products. Resolution of the Cabinet of Ministers of Ukraine of February 20, 2013, No. 120].

3. Electronic resource interfax.com.ua.

Надійшла до редакції 10.12.2021, розглянута на редколегії 11.12.2021.

\section{ANALYSIS OF THE HEAVY UAVS DEVELOPMENT IN UKRAINE ON THE EXAMPLE OF THE HORLYTSIA PROJECT}

Development of domestic UAVs with a takeoff weight of over $150 \mathrm{~kg}$ has been analized. A foreign example of the development of UAV is presented and estimated. A trend line for the development of foreign UAVs Class II (150 kg - $600 \mathrm{~kg}$ ), Class III (>600 kg) in the period 2007-2021 has been revealed on the example of Turkey. The predicted development trend of the UAVs in Ukraine, based on the further development of the Gorlitsa project (ANTONOV SE), has been determined. This is a completely new, complex and promising direction in the development of weapons and military equipment. The project is a fully domestic cooperation of co-executors of the project in all components of the UAV. In 2016 more than 20 domestic UAVs passed the stage of defining departmental tests at the ranges of the Armed Forces of Ukraine, the controlled operation of these UAVs in the army continues, the rest have already completed this operation, passed the procedure for putting into service, accepted for service, are mass-produced and supplied to the Army. A variant of the roadmap for the development of heavy UAVs in Ukraine for the period up to 2030 has been proposed.

Key words: unmanned aerial vehicle system, UAV classification, takeoff weight, development work, ground control station, noise-free radio link, NATO STANAG standards, development trend, roadmap.

\section{Відомості про авторів}

Двейрін Олександр Захарович - Перший заступник генерального директора - Генеральний конструктор ДП «АНТОНОВ»

Воробйов Микола Митрофанович - Директор програм безпілотних авіаційних комплексів ДП «АНТОНОВ»

Жданов Сергій Васильович - Провідний конструктор ДП «АНТОНОВ»

About the Authors:

Oleksandr Dveyrin- First Deputy General Director, General Designer of ANTONOV SE

Mykola Vorobyov - Director of Programs of Unmanned Aerial Vehicles of ANTONOV SE

Serhiy Zhdanov - Leading Designer of ANTONOV SE 